\title{
Chemical control of stalk regrowth in glyphosate-resistant transgenic cotton
}

\author{
Alexandre C. de B. Ferreira ${ }^{1}$, Julio C. Bogiani², Valdinei Sofiatti ${ }^{3}$ \& João L. da Silva Filho ${ }^{1}$ \\ ${ }^{1}$ Embrapa Algodão/Núcleo de Cerrado. Santo Antônio de Goiás, GO. E-mail: alexandre-cunha.ferreira@embrapa.br (Corresponding author) - ORCID: \\ 0000-0003-4612-0131; joao.silva-filho@embrapa.br - ORCID: 0000-0002-1570-361X \\ ${ }^{2}$ Embrapa Algodão/Núcleo de Luis Eduardo Magalhães. Luis Eduardo Magalhães, BA. E-mail: julio.bogiani@embrapa.br - ORCID: 0000-0002-3357-7944 \\ ${ }^{3}$ Embrapa Algodão/Núcleo de Palmas. Palmas, TO. E-mail: valdinei.sofiatti@embrapa.br - ORCID: 0000-0002-9563-5855
}

\section{Key words:}

Gossypium hirsutum

transgenic

stalk regrowth

herbicides

environment

\begin{abstract}
A B S T R A C T
Cotton stalk regrowth must be controlled after harvest to ensure the phytosanitary quality and sustainability of cotton farming systems. Mechanical destruction generally does not conform to the no-tillage system, and the control of cotton stalk regrowth by herbicides is little studied in Brazil. The objective of this study was to evaluate the efficiency of herbicides to control glyphosate-resistant transgenic cotton stalk regrowth. The study was conducted in three environments of the Brazilian Cerrado region, two in Santa Helena de Goiás (SHGO), during 2013 and 2014, and one in Luís Eduardo Magalhães (LEM-BA) in 2014. In each of the three environments, the experiment was carried out in a randomized complete block with four replications. Each experiment consisted of different combinations of herbicides and one untreated control. Cotton stalk regrowth was influenced by the three environments. Two sequential 2,4-D amine applications, each with $1,000 \mathrm{~g} \mathrm{ha}^{-1}$ of acid equivalent, resulted in better cotton stalk destruction, albeit with $4.9,16.9$ and $36.9 \%$ of cotton stalk regrowth in SHGO 2013 and 2014, and LEM-BA 2014, respectively. A single application of 2,4-D amine and a 2,4-D amine spraying followed by the application of carfentrazone-ethyl, paraquat, saflufenacil, paraquat + diuron or glufosinate-ammonium are not effective to control glyphosate-resistant transgenic cotton stalk regrowth. The best destruction of cotton stalk regrowth occurs with two sequential applications of 2,4-D amine.
\end{abstract}

\section{Palavras-chave:}

Gossypium hirsutum

transgênico

rebrota

herbicidas

ambiente

\section{Controle químico dos restos culturais do algodoeiro resistente ao glifosato}

\section{R E S U M O}

A eliminação dos restos culturais do algodoeiro após a colheita é fundamental para a qualidade fitossanitária e sustentabilidade da cotonicultura. A destruição mecânica geralmente não condiz com os princípios do sistema plantio direto, e o controle por meio de herbicidas é pouco estudado no Brasil. Objetivou-se com este estudo avaliar a eficiência da destruição química dos restos culturais do algodoeiro geneticamente modificado para resistência ao glifosato. O estudo foi conduzido em três ambientes do cerrado, sendo dois em Santa Helena de Goiás (SHGO), nos anos de 2013 e 2014, e um em Luís Eduardo Magalhães (LEM-BA), em 2014. Em cada um dos três ambientes foi instalado um experimento no delineamento de blocos ao acaso, com quatro repetições. Cada experimento constou de diferentes associações de herbicidas e uma testemunha sem controle. A porcentagem de rebrota variou entre os três ambientes. Duas aplicações sequenciais de 2,4-D amina, cada uma com $1.000 \mathrm{~g} \mathrm{ha}^{-1}$ do equivalente ácido, resultaram em melhor controle dos restos culturais do algodoeiro, porém com 4,9, 16,9 e 36,9\% de plantas rebrotadas em SHGO 2013 e 2014, e LEM-BA 2014, respectivamente. Uma única aplicação de 2,4-D amina e uma aplicação de 2,4-D amina seguida de uma aplicação dos herbicidas carfentrazona, paraquat, saflufenacil, paraquat + diuron ou glufosinato de amônio não controlam eficientemente os restos culturais do algodoeiro transgênico resistente ao glifosato. $\mathrm{O}$ melhor controle químico dos restos culturais ocorre com duas aplicações sequenciais de 2,4-D amina. 


\section{INTRODUCTION}

Cotton (Gossypium hirsutum L.), after harvest, normally regrowth and produces new reproductive structures (Greenberg et al., 2007), which in the off-season period serve as refuge and feed for the boll weevil (Anthonomus grandis) (Yang et al., 2006; Greenberg et al., 2007; Santos, 2015), the main pest of the Brazilian cotton crop (Miranda \& Rodrigues, 2015).

Cotton stalk destruction after harvest is a very important strategy of the integrated pest management (Lima et al., 2013; Grigolli et al., 2015). After harvest, crop residues and stalks can be eliminated by soil tillage implements such as plow and plowing harrow (Bianchini \& Borges, 2013; Ribeiro et al., 2015; Sofiatti et al., 2015), although devices have been developed to improve the operational capacity of the destruction and promote minimum soil mobilization (Sofiatti et al., 2015). Nevertheless, this form of destruction, besides having low operational efficiency, does not always conform to the principles of the no-till system (NTS), a conservation system that favors the mitigation of greenhouse gases (Corbeels et al., 2016; Sant-Anna et al., 2017).

Chemical destruction, through herbicides, is an option to control stalk regrowth (Yang et al., 2011) and, besides having higher operational efficiency, it does not compromise the NTS. Stalks of conventional cultivars not transgenic for the resistance to herbicides can be controlled with glyphosate and 2,4-D (Yang et al., 2006; Greenberg et al., 2007; Ribeiro et al., 2015). However, chemical destruction of glyphosate-resistant cotton stalks has been limited due to the ineffectiveness of this herbicide for these transgenic cultivars.

The present study aimed to determine the effectiveness of herbicides in the control of the regrowth of glyphosate-resistant genetically modified cotton stalks

\section{Material AND Methods}

Eight treatments were studied, one of which was an untreated control and the others were composed of different associations of herbicides (Table 1). The experimental design was randomized complete blocks, with four replicates. The study was carried out under field conditions, in three environments of the Cerrado, two in Santa Helena de Goiás ( $17^{\circ} 49^{\prime} 52^{\prime \prime}$ S, 50 35' 55" W, 577 m of altitude), in 2013 and 2014, and one in Luís Eduardo Magalhães, BA ( $12^{\circ} 05^{\prime} 34^{\prime \prime}$ S, 45 $42^{\prime} 37^{\prime \prime} \mathrm{W}, 756 \mathrm{~m}$ of altitude), in 2014. Before the experiments, a composite soil sample was collected in the 0-20 cm layer for chemical and granulometric analyses, conducted according to the methodology of EMBRAPA (Silva, 2009), with results presented in Table 2. The three environments, considered as factors of the study, represent two regions with different edaphoclimatic characteristics (Table 2 and Figure 1).
Table 1. Herbicides treatments studied to control cotton stalk regrowth

\begin{tabular}{|c|c|}
\hline First application (1) & Second application (2) \\
\hline \multicolumn{2}{|c|}{ Untreated control ${ }^{(3)}$} \\
\hline 2,4-D amine ${ }^{(4)}$ & 2,4-D amine (4) $^{(4)}$ \\
\hline 2,4-D amine ${ }^{(4)}$ & Carfentrazone ${ }^{(5)}$ \\
\hline 2,4-D amine ${ }^{(4)}$ & Paraquat ${ }^{(6)}$ \\
\hline 2,4-D amine ${ }^{(4)}$ & Saflufenacil ${ }^{(7)}$ \\
\hline 2,4-D amine ${ }^{(4)}$ & Paraquat $^{(6)}+$ diuron $^{(8)}$ \\
\hline 2,4-D amine ${ }^{(4)}$ & - \\
\hline 2,4-D amine ${ }^{(4)}$ & Glufosinate-ammonium $^{(9)}$ \\
\hline
\end{tabular}

(1)Sprayings performed after using stalk shredder, when at least $50 \%$ of the stalks had shoots longer $3 \mathrm{~cm}$ or leaves with diameter larger than $2.5 \mathrm{~cm}$; (2) Sprayings at 41,34 and 31 days after the first application, respectively for Santa Helena de Goiás in 2013 and 2014, and Luís Eduardo Magalhães in 2014; ${ }^{(3)}$ Sprayed only with water + mineral oil $\left(756 \mathrm{~g} \mathrm{ha}^{-1}\right.$ of active ingredient - a.i. aliphatic hydrocarbon); (4) $1,000 \mathrm{~g} \mathrm{ha}^{-1}$ of the acid equivalent - a.e.; ${ }^{(5)} 50 \mathrm{~g} \mathrm{ha}^{-1}$ of the a.i.; ${ }^{(6)} 400 \mathrm{~g} a^{-1}$ of the a.i.; $\left.{ }^{7}\right) 49 \mathrm{~g} \mathrm{ha}^{-1}$ of the a.i.; ${ }^{(8)} 200 \mathrm{~g} \mathrm{ha}^{-1}$ of the a.i.; (9) $400 \mathrm{~g} \mathrm{ha}^{-1}$ of the $a . \mathrm{i}$.

In the three environments, the spacing between rows was $0.76 \mathrm{~m}$, with eight plants $\mathrm{m}^{-1}$. The experimental plot comprised six 5-m-long rows and the two central rows were used for evaluations, disregarding $0.5 \mathrm{~m}$ on each end. Sowing was performed in the first half of December, using the cultivar BRS 371 Roundup Ready Flex (RF), which has large size and late cycle.

At harvest, performed on July 17, 2013 (SHGO), July 8, 2014 (SHGO) and June 30, 2014 (LEM-BA), cotton plants were about 118,123 and $116 \mathrm{~cm}$ tall in these three environments, respectively. After cotton was harvested by a picker machine, a stalk shredder was used in the mechanical fragmentation of cotton plants, at $20 \mathrm{~cm}$ height. Immediately before herbicide application, the number of plants mechanically ground in each experimental plot was quantified to determine the number of stalks after applying the herbicide treatments, originating the regrowth percentage.

The first application was performed after using the stalk shredder, when at least $50 \%$ of stalks had shoots longer than $3 \mathrm{~cm}$ or leaves with diameter larger than $2.5 \mathrm{~cm}$. The second application occurred at 41,34 and 31 days after the first application, respectively for SHGO 2013 and 2014, and LEMBA 2014, when stalks had the same characteristics established for the first application.

Herbicide doses were defined based on what has been reported and recommended for the control of some dicotyledonous weeds. All sprayings used a mixture volume of $200 \mathrm{~L} \mathrm{ha}^{-1}$, with addition of mineral oil $\left(756 \mathrm{~g} \mathrm{ha}^{-1}\right.$ of the a.i. aliphatic hydrocarbon).

Twenty days after the second application of the herbicides, stalks were counted considering those with viable vegetative structures. Regrowth percentage calculation considered the number of stalks in relation to the total number of plants before treatment application.

Table 2. Results of soil analysis in the $0.20 \mathrm{~cm}$ layer before the experiments, in the environments Santa Helena de Goiás (SHGO) and Luís Eduardo Magalhães (LEM-BA)

\begin{tabular}{|c|c|c|c|c|c|c|c|c|c|c|c|c|c|}
\hline \multirow{2}{*}{ Environment } & $\mathrm{pH}^{1}$ & $\mathbf{P}^{2}$ & $\mathbf{K}^{3}$ & $\mathrm{Ca}^{4}$ & $\mathrm{Mg}^{5}$ & $\mathrm{H}+\mathrm{Al}^{6}$ & $S^{7}{ }^{7}$ & CEC $^{8}$ & \multirow{2}{*}{$\begin{array}{l}\mathbf{V}^{9} \\
\%\end{array}$} & \multirow{2}{*}{$\begin{array}{c}0 M^{10} \\
g^{k^{-1}}\end{array}$} & \multirow{2}{*}{\multicolumn{3}{|c|}{$\frac{\text { Silt }}{\mathrm{g} \mathrm{kg}^{-1}}$}} \\
\hline & $\mathrm{CaCl}_{2}$ & \multicolumn{2}{|c|}{$\mathrm{mg} \mathrm{dm}^{-3}$} & \multicolumn{5}{|c|}{$\mathrm{mmol}_{\mathrm{c}} \mathrm{dm}^{-3}$} & & & & & \\
\hline SHGO 2013 & 5.2 & 10.5 & 85 & 35 & 10 & 52 & 47.2 & 99.2 & 47.6 & 3.4 & 486 & 217 & 297 \\
\hline SHGO 2014 & 4.7 & 13.3 & 112 & 33 & 12 & 55 & 47.9 & 103.0 & 46.6 & 4.1 & 557 & 168 & 275 \\
\hline LEM-BA 2014 & 5.9 & 38.0 & 86 & 25 & 3 & 14 & 30.2 & 44.2 & 68.3 & 1.4 & 160 & 60 & 780 \\
\hline
\end{tabular}

${ }^{1} \mathrm{pH}$ in $\mathrm{CaCl}_{2}$ at soil:water ratio of $1: 2.5 ;{ }^{2}$ Available phosphorus; ${ }^{3}$ Potassium; ${ }^{4} \mathrm{Calcium} ;{ }^{5}$ Magnesium; ${ }^{6}$ Exchangeable acidity; ${ }^{7}$ Sum of bases $=\mathrm{Ca}+\mathrm{Mg}+\mathrm{K} ;{ }^{8} \mathrm{Cation}$ exchange capacity $=\mathrm{H}$ $+\mathrm{Al}+\mathrm{SB} ;{ }^{9}$ Saturation by exchangeable bases $=\mathrm{SB} / \mathrm{CEC} 100$ and ${ }^{10}$ Organic matter 


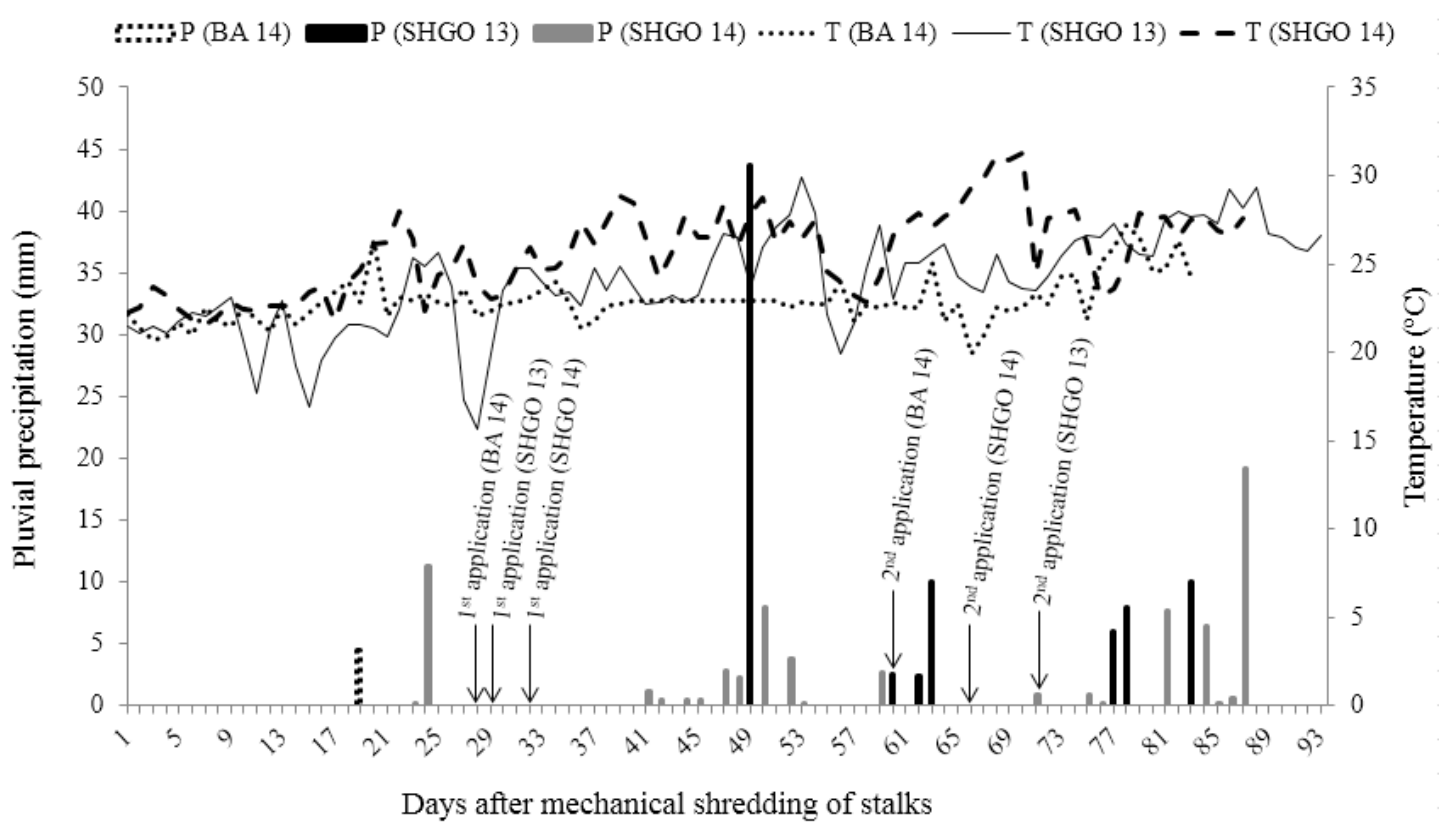

Figure 1. Pluvial precipitation (P) (vertical bars) and mean temperature (T) (horizontal lines), from the mechanical shredding of cotton stalks until the evaluation of herbicide efficiency, in Santa Helena de Goiás 2013 (SHGO 13), 2014 (SHGO 14) and Luís Eduardo Magalhães - Bahia 2014 (LEM-BA 14)

Regrowth percentage data were subjected to analysis of variance, individual (per environment) and joint. All means were compared, within each environment, by Tukey test at $5 \%$ significance level. The levels of the factor environment were also compared by Tukey test at $5 \%$ probability level. This strategy was selected not only because of the significance of the source of variation of the interaction, which indicated no consistent behavior of the herbicides in the three environments, but also because of the environmental difference, especially soil and climate characteristics.

\section{Results AND Discussion}

Regrowth percentage was significantly influenced by the herbicides and environments, and herbicide $\mathrm{x}$ environment interaction (Table 3).

The three different environments significantly differed from one another $(\mathrm{LSD}=5.5)$ with respect to regrowth percentage, which was equal to $35.7 \%$ for SHGO in 2013, 54.2\% for LEMBA in 2014 and $29.5 \%$ for SHGO in 2014.

Since the Herbicide $\mathrm{x}$ Environment interaction was significant $(p<0.01)$, regrowth percentage data are presented separately for each environment. The differences in the control of stalk regrowth between the three environments are probably

Table 3. Summary of joint analysis of variance for regrowth percentage of glyphosate-resistant genetically modified cotton, as a function of herbicides and environments

\begin{tabular}{lcc}
\hline \multicolumn{1}{c}{ Source of variation } & $\begin{array}{c}\text { Degrees } \\
\text { of freedom }\end{array}$ & $\begin{array}{c}\text { MS } \\
\text { (20 DAS) }\end{array}$ \\
Herbicide & 7 & $2,829.8^{* *}$ \\
Environment & 2 & $5,274.0^{* *}$ \\
Herbicide x Environment & 14 & $290.1^{* *}$ \\
Repetition (environment) & 9 & 601.5 \\
Error & 63 & 84.2 \\
Coefficient of variation (CV) & & 23.06 \\
Overall mean & & 39.8 \\
\hline
\end{tabular}

MS - Mean square; ** Significant at 0.01 probability level by $\mathrm{F}$ test due to differences of soil moisture contents in the different sites, which can be observed through the pluvial precipitation data (Figure 1), corroborated by the different potentials of water accumulation attributed to organic matter contents and soil texture (Table 2). Basically, there were no marked differences in crop management that could influence regrowth percentage in the different environments. Plants exhibited similar growth and development, and plant height at harvest varied from 116 to $123 \mathrm{~cm}$, indicating adequate growth control with mepiquat chloride.

Two sequential applications of 2,4-D, each one with $1,000 \mathrm{~g} \mathrm{ha}^{-1}$ of the acid equivalent (a.e.) resulted in better control of glyphosate-resistant cotton stalk regrowth in the three environments studied (Table 4). For the environment SHGO in 2013 the regrowth was $4.9 \%$ after two applications of $2,4-\mathrm{D}$, i.e., the control was approximately $95 \%$. In 2014 , the control was $83.1 \%$ in SHGO and $63.1 \%$ in LEM-BA. Silva et al. (2015) comment that it is usually difficult to obtain $100 \%$

Table 4. Regrowth percentage of glyphosate-resistant genetically modified cotton, as a function of herbicides and environments: Santa Helena de Goiás (SHGO), in 2013 and 2014, and Luís Eduardo Magalhães (LEM-BA) in 2014

\begin{tabular}{|c|c|c|c|c|}
\hline \multirow[b]{2}{*}{$\begin{array}{c}\text { First } \\
\text { spraying }^{1}\end{array}$} & \multirow[b]{2}{*}{$\begin{array}{l}\text { Second } \\
\text { spraying }^{2}\end{array}$} & \multicolumn{3}{|c|}{ Regrowth $(\%)^{3}$} \\
\hline & & $\begin{array}{l}\text { SHGO } \\
2013\end{array}$ & $\begin{array}{l}\text { SHGO } \\
2014\end{array}$ & $\begin{array}{l}\text { LEM-BA } \\
2014\end{array}$ \\
\hline \multicolumn{2}{|c|}{ Untreated control } & $82.4 \mathrm{a}$ & $57.5 \mathrm{a}$ & $76.4 \mathrm{a}$ \\
\hline 2,4-D amine & 2,4-D amine & $4.9 d$ & $16.9 \mathrm{c}$ & $36.9 \mathrm{~b}$ \\
\hline 2,4-D amine & Carfentrazone & $29.4 \mathrm{C}$ & $28.9 \mathrm{bc}$ & $60.7 \mathrm{ab}$ \\
\hline 2,4-D amine & Paraquat & $33.6 \mathrm{bc}$ & $18.6 \mathrm{c}$ & $57.9 \mathrm{ab}$ \\
\hline 2,4-D amine & Saflufenacil & $26.0 \mathrm{c}$ & $36.7 \mathrm{~b}$ & $49.8 a b$ \\
\hline 2,4-D amine & Paraquat + diuron & $34.9 \mathrm{bc}$ & $23.9 \mathrm{bc}$ & $52.8 \mathrm{ab}$ \\
\hline 2,4-D amine & - & $52.2 \mathrm{~b}$ & $31.2 \mathrm{bc}$ & $57.8 \mathrm{ab}$ \\
\hline 2,4-D amine & Glufosinate-ammonium & $22.2 \mathrm{~cd}$ & $22.4 \mathrm{bc}$ & $41.2 \mathrm{~b}$ \\
\hline \multicolumn{5}{|c|}{ 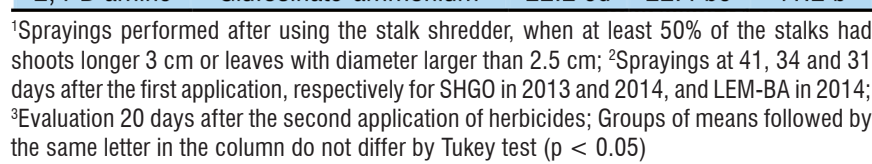 } \\
\hline
\end{tabular}


control of stalk regrowth for conventional cotton not resistant to herbicide, even when glyphosate is applied. According to Greenberg et al. (2007), although 2,4-D does not eliminate all stalks, the remaining living plants produce virtually no fruits due to the phytotoxic effect of 2,4-D. Nonetheless, in the absence of reproductive structures, the boll weevil can feed on vegetative structures, such as the tips and petioles of cotton leaves (Azambuja \& Degrande, 2014), which favors its survival in the off-season period if the stalks are not completely destroyed.

In general, lower regrowth percentages were observed in all treatments with herbicides, compared with the untreated control, except for LEM-BA in 2014. In the Brazilian Cerrado region, the absence of more effective control, as observed in the present study, can favor the survival of boll weevil (Ribeiro et al., 2015), which is the reason why the Brazilian legislation of plant sanitary defense of the states Goiás and Bahia recommends that, during the sanitary fallow period, there should be no cotton stalk regrowth, i.e., all plants should be destroyed by chemical (herbicide) or physical (mechanical) processes.

In the Cerrado of Goiás, the first application of 2,4-D, and then another one exclusively with the herbicides carfentrazoneethyl, paraquat, saflufenacil, paraquat + diuron or glufosinateammonium, resulted in regrowth percentage higher than $22 \%$ in 2013 and more than $18 \%$ in 2014 . These treatments significantly differed from the untreated control and, despite the reduction in stalk regrowth percentage, the control was not sufficient to meet the sanitary fallow period.

These same herbicide treatments were not much effective in the control of Roundup Ready Flex (RF) cotton regrowth in Bahia, where the highest regrowth percentages were observed. Ten days after the first herbicide application in LEM-BA there was pluvial precipitation of $4.4 \mathrm{~mm}$ and then no rains occurred along the experiment (Figure 1). Such condition, besides compromising the action of the herbicides, did not prevent cotton regrowth. Even in extreme situations of water deficit in Western Bahia, there was $76.4 \%$ of regrowth in the untreated control, certainly due to the characteristics of the cotton plant and its origin in arid and semi-arid regions.

The high survival percentage of cotton stalks after the applications of the herbicides should be related not only to the characteristics of the plant and climate condition, but also to the particularities of absorption and translocation of the studied herbicides. Carfentrazone-ethyl and saflufenacil (inhibitors of the enzyme protoporphyrinogen oxidase), paraquat (inhibitor of photosynthesis - Photosystem I) and diuron (inhibitor of photosynthesis - Photosystem II) are little mobile or immobile through the phloem, so that their actions are basically of contact (Grossmann et al., 2010; Oliveira Júnior, 2011). On the other hand, glufosinate-ammonium, inhibitor of the enzyme glutamine synthetase, is considered as a herbicide of limited translocation in the phloem because its application causes rapid phytotoxicity due to the accumulation of ammonia in plant cells (Brunharo et al., 2014). Thus, the localized action of the herbicides in the shoots of cotton stalks, which showed poorly vigorous vegetative structures, exposed to environments with low water contents in the soil, low relative air humidity, milder temperatures and with dust accumulated on the leaves and regrowths, certainly contributed to the reduction in the metabolic activity of cotton stalks and to the lower effectiveness of the herbicides.

For the environment SHGO, in both years, pluvial precipitations occurred between the first and second herbicide applications, until the evaluation of treatment effects (Figure 1), which must have contributed to the better control of regrowth, especially in the treatment with the systemic herbicide 2,4-D. Herbicide efficiency to control plants originated from cotton stalk regrowth, as occurs for weeds, is determined among other factors by climate conditions, especially temperature, water content in the soil and relative air humidity (Cieslik et al., 2013; Matzenbacher et al., 2014). These environmental conditions interfere with various morphological and physiological characteristics of plants, such as the composition and structure of leaf cuticle, stomatal opening and closure, thickness and constitution of the plant bark (Matzenbacher et al., 2014), influencing the capacity of absorption and translocation of the herbicides in the plants (Cieslik et al., 2013).

The best controls of regrowth were observed with two applications of 2,4-D, probably due to the high sensitivity of cotton plants to this herbicide (Byrd et al., 2016). Despite that, considering the mean population at harvest, about 90,000 plants ha ${ }^{-1}$, it was observed that in the best treatments there would still be 4,410, 15,210 and 33,210 living plants ha ${ }^{-1}$, for SHGO in 2013 and 2014, and LEM-BA 2014, respectively. According to Crafts (1956), 2,4-D is a systemic herbicide with translocation through xylem and phloem, and its translocation is reduced when soil water content decreases, resulting in lower accumulation in the apical meristems of stem and roots, the sites of its action.

In general, the lowest regrowth percentages were obtained with two applications of 2,4-D, but the results were not satisfactory because many cotton plants regrew. Therefore, other herbicides, doses and periods of application should be studied aiming at chemical destruction of glyphosate-resistant genetically modified cotton stalks, so that the Brazilian cotton production does not become unviable due to phytosanitary problems.

\section{Conclusions}

1. The regrowth of glyphosate-resistant cotton stalks is influenced by the environment.

2. The best control of glyphosate-resistant cotton stalks is obtained with two sequential applications of 2,4-D amine.

3. The herbicides carfentrazone-ethyl, paraquat, saflufenacil, paraquat + diuron and glufosinate-ammonium, applied only once, after the 2,4-D amine, do not efficiently control glyphosate-resistant cotton stalk regrowth.

\section{Literature Cited}

Azambuja, R.; Degrande, P. E. Trinta anos do bicudo-do-algodoeiro no Brasil. Arquivos do Instituto Biológico, v.81, p.377-410, 2014. https://doi.org/10.1590/1808-1657000012013 
Bianchini, A.; Borges, P. H. de M. Evaluation of cotton stalks destroyers. Engenharia Agrícola, v.33, p.965-975, 2013. https:// doi.org/10.1590/S0100-69162013000500008

Brunharo, C. A. de C. G.; Christoffoleti, P. J.; Nicolai, M. Aspectos do mecanismo de ação do amônio glufosinato: Culturas resistentes e resistência de plantas daninhas. Revista Brasileira de Herbicidas, v.13, p.163-177, 2014. https://doi.org/10.7824/rbh.v13i2.293

Byrd, S. A.; Collins, G. D.; Culpepper, A. S.; Dodds, D. M.; Edmisten, K. L.; Wright, D. L.; Morgan, G. D.; Baumann, P. A.; Dotray, P. A.; Manuchehri, M. R.; Jones, A.; Grey, T. L.; Webster, T. M.; Davis, J. W.; Whitaker, J. R.; Roberts, P. M.; Snider, J. L.; Porter, W. M. Cotton stage of growth determines sensitivity to $2,4-\mathrm{D}$. Weed Technology, v.30, p.601-610, 2016. https://doi.org/10.1614/WTD-15-00191.1

Cieslik, L. F.; Vidal, R. A.; Trezzi, M. M. Fatores ambientais que afetam a eficácia de herbicidas inibidores da ACCase: Revisão. Planta Daninha, v.31, p.483-489, 2013. https://doi.org/10.1590/ S0100-83582013000200026

Corbeels, M.; Marchão, R. L.; Siqueira Neto, M.; Ferreira, E. G.; Madari, B. E.; Scopel, E.; Brito, O. R. Evidence of limited carbon sequestration in soils under no-tillage systems in the Cerrado of Brazil. Scientific Reports, v.6, p.1-8, 2016. https://doi.org/10.1038/ srep21450

Crafts, A. S. I. The mechanism of translocation: Methods of study with $C^{14}$-labeled 2,4-D. Hilgardia, v.26, p.287-334, 1956. https:// doi.org/10.3733/hilg.v26n06p287

Greenberg, S. M.; Sparks Júnior, A. N.; Norman Júnior, J. W.; Coleman, R.; Bradford, J. M.; Yang, C.; Sappington, T. W.; Showler, A. Chemical cotton stalk destruction for maintenance of host-free periods for the control of overwintering boll weevil in tropical and subtropical climates. Pest Managment Science, v.63, p.372-380, 2007. https://doi.org/10.1002/ps.1348

Grigolli, J. F. J.; Crosariol Netto, J.; Izeppi, T. S.; Souza, L. A. de; Fraga, D. F.; Busoli, A. C. Infestação de Anthonomus grandis (Coleoptera: Curculionidae) em rebrota de algodoeiro. Pesquisa Agropecuária Tropical, v.45, p.200-208, 2015. https://doi.org/10.1590/1983$40632015 \mathrm{v} 4532296$

Grossmann, K.; Niggeweg, R.; Christiansen, N.; Looser, R.; Ehrhardt, T. The herbicide saflufenacil $\left(\right.$ Kixor $^{\mathrm{ra}}$ ) is a new inhibitor of protoporphyrinogen IX oxidase activity. Weed Science Society of America, v.58, p.1-9, 2010. https://doi.org/10.1614/WS-D09-00004.1

Lima, I. S. J. de; Degrande, P. E.; Miranda, J. E.; Santos, W. J. dos. Evaluation of the boll weevil Anthonomus grandis Boheman (Coleoptera: Curculionidae) suppression program in the state of Goiás, Brazil. Neotropical Entomology, v.42, p.82-88, 2013. https://doi.org/10.1007/s13744-012-0083-3
Matzenbarcher, F. O.; Vidal, R. A.; Merotto Júnior, A.; Trezzi, M. M. Environmental and physiological factors that affect the efficacy of herbicides that inhibit the enzyme protoporphyrinogen oxidase: A literature review. Planta Daninha, v.32, p.457-463, 2014. https:// doi.org/10.1590/S0100-83582014000200024

Miranda, J. E.; Rodrigues, S. M. M. História do bicudo no Brasil. In: Belot, J. L. (ed.) O bicudo-do-algodoeiro (Anthonomus grandis Boh., 1843) nos cerrados brasileiros: Biologia e medidas. Cuiabá: Instituto Mato-grossense do Algodão, 2015. Cap.1, p.11-45.

Oliveira Júnior, R. S. Mecanismos de ação de herbicidas. In: Oliveira Júnior, R. S.; Constantin, J. (ed.). Biologia e manejo de plantas daninhas. 1.ed. Curitiba: Omnipax Editora Ltda, 2011. Cap.7, p.141-191.

Ribeiro, E. B.; Castellani, M. A.; Silva, C. A. D. da; Melo, T. L.; Silva, G. dos S.; Vale, W. S. do; Santos, A. S. Methods of cotton stalk destruction and survival of boll weevil. Pesquisa Agropecuária Brasileira, v.50, p.993-998, 2015. https://doi.org/10.1590/S0100204X2015001100001

Sant-Anna, S. A. C. de; Jantalia, C. P.; Sá, J. M.; Vilela, L.; Marchão, R. L.; Alves, B. J. R.; Urquiaga, S.; Boddey, R. M. Changes in soil organic carbon during 22 years of pastures, cropping or integrated crop/livestock systems in the Brazilian Cerrado. Nutrient Cycling in Agroecosystems, v.108, p.101-120 2017. https://doi. org/10.1007/s10705-016-9812-z

Santos, W. J. Medidas estratégicas de controle do bicudo-doalgodoeiro (Anthonomus grandis Boh., 1843). In: Belot, J. L. (ed.) O bicudo-do-algodoeiro (Anthonomus grandis Boh., 1843) nos cerrados brasileiros: Biologia e medidas de controle. Cuiabá: Instituto Mato-grossense do Algodão, 2015. Cap.4, p.79-94.

Silva, F. C. da. Manual de análises químicas de solos, plantas e fertilizantes. 2.ed. Brasília: Embrapa Informação Tecnológica, 2009. 627p.

Silva, O. R. R. F.; Sofiatti, V.; Ferreira, A. C. B.; Lamas, F. M. Destruição dos restos culturais do algodoeiro. In: Freire, E. C. (ed.) Algodão no cerrado do Brasil. 3.ed. Brasília: Gráfica e Editora Positiva, 2015. Cap.5, p.135-150.

Sofiatti, V.; Silva, O. R. R. F.; Andrade Júnior, E. R. de; Ferreira, A. C. de B. Destruição dos restos culturais do algodoeiro. Campina Grande: Embrapa Algodão, 2015. 20p. Boletim de Pesquisa e Desenvolvimento, 96

Yang, C.; Greenberg, S. M.; Everitt, J. H.; Fernandez, C. J. Assessing cotton defoliation, regrowth control and root rot infection using remote sensing technology. International Journal of Agricultural and Biological Engineering, v.4, p.1-11, 2011.

Yang, C.; Greenberg, S. M.; Everitt, J. H.; Norman Júnior, J. W. Assessing cotton stalk destruction with herbicides using remote sensing technology. Journal of Cotton Science, v.10, p.136-145, 2006. 